\title{
LINGVOCULTURAL NATURE OF THE VERNACULAR NAMES OF AUTHENTIC DISHES IN ENGLISH, UKRAINIAN, FRENCH AND POLISH LANGUAGES OF THE XIX ${ }^{\mathrm{TH}}$ CENTURY
}

\author{
Oleksandra Palchevska \\ Assistant Professor, PhD, Lviv State University of Life Safety, \\ e-mail: palch56@ukr.net, orcid.org/0000-0002-2090-4870, Ukraine
}

\begin{abstract}
The article deals with the study of nominative units designating authentic dishes and drinks in the 19th century vernacular of the Ukrainian, English, French and Polish languages as well as the features revealing their linguistic and cultural specificity. The relevance of such research is determined by the lack of comprehensive studies of the gluttony phenomenon of in the Ukrainian, English, French and Polish languages, as well as the need to delineate the linguosemiotic and linguocultural parameters of the 19th century glutonic names. The author reveals the meaning of the term "nominative units linguocultural marking", defines its differential features; outlines the theoretical basis for the study of nominative units for the designation of authentic foods and beverages; analyzes metaphorical models of such nominations creation; finds out linguocultural features of glutonic names; describes the main methods of nomination (motivational features and the most productive word-forming models).

Food is an integral part of human life, yet it is specific to a particular national community. The vitality of any nation is reflected in its cuisine. The natural, social and economic conditions of each nation also affect what do people eat. The gastronomy area we are exploring is one of greatest nationally specific areas. With the development of agriculture and the market, national cuisine and gastronomy are constantly evolving, which is reflected in the vocabulary and phraseology of the language. Collective memory and national phraseology absorb and preserve sociocultural concepts and associations that are connected with product names and national cuisine that have evolved over the centuries.

Culture is a complex phenomenon that contains material, spiritual and social components. The very process of communication between people is carried out by means of a set of non-verbal (sound, visual, haptic, facial, gestural, kinetic, proxemic, etc.) and verbal or languge (oral and written) ways of transmitting culturally relevant information. Both verbal and non-verbal codes of culture reflect the external aspect of culture, while the internal aspect is related to its axiological system.
\end{abstract} ethnoculture.

Keywords: 19th century vernacular, word picture, nomination, motivation,

DOI: http://dx.doi.org/10.23856/3611

\section{Introduction}

V. Humboldt was one of the first in the field of linguistics who attempted to solve the interaction between language and culture problem. The scientist asked the question: can we talk about a universal picture of the world, or does each nation perceive reality and translate the results of that perception in a language differently? According to V. Humboldt, "drawing on any language, one can draw a conclusion about the national character" (Humboldt, 1985: 234). 
The core of the national-cultural space is organized in some way national cognitive base. This knowledge records the experience understanding and the reality comprehending thinking rules, norms and stereotypes acquired by previous generations of a community.

Different forms and levels of the language system convey the mentality of the people in different ways. This process is double in its nature: static and dynamic. In the first case, it can be established empirically that words, phrases and grammatical forms are capable of reflecting particular ethnoculture elements in their meanings. In the second case, this property is manifested in the peculiarities of the use of linguistic units in speech, the choice of linguistic elements in the language, which is made by a representative of a particular culture and illustrates what are the reality elements, as well as how their relationships and properties stand out in the speaker's mind. "Languages differ not only in what they "have", but also in how they use what they have" (Karasyk, 2005:15). In this article, we study first and foremost the static aspect of the cultural values in language transference process, because language is considered as a system that exists in the memory not of its individual medium but of the linguistic collective as a whole at a fixed point in time. In modern linguistics, much attention is paid to the study of both these facts, especially in ethnolinguistic and lingvocultural researches.

\section{The Cultural Component of a Word in the Vernacular Language}

As it is known, the word not only transmits current information in everyday language communication, but at the same time broadcasts socio-historical, intellectual, expressive, evaluative data in the linguistic and national spheres. Such pieces of information can be considered a national-cultural component in the words' semantic structure. It is obvious that individual ethnocultures have certain universals that arise as a result of the similar traits in the human development socio-historical and biological conditions presence. However, there are many differences related to the indiscreet nature of participants in ethnoculture, which rejects its full understanding from the another culture's standpoint.

The language and thщгпре are two independent categories, although closely related. According to this position, we distinguish two pictures of the world - conceptual and symbolic or linguistic.

Linguistic studies of recent years are marked by increased interest in the issue of the correlation of conceptual and linguistic pictures of the world. Modern scientists, considering the relationship of these models of the world (Brutyan, 1973; Karaulov, 1996; Serebrennikov, 1988; Kubryakova, 1991 and others.) define the first as "the language of thought", "the language of the brain", but disagree regarding the nature, status and correlations between these systems.

From the very birth, a person begins to get acquainted with the world, not having this communication skills, gradually collecting information about it. Channels of human sensory perception actively participate in the process of the world cognition, and, as a result, this or that individual already has some information about it.

A person learns to distinguish and identify the knowledge objects. In this way, a system of information about the world, is designed by man himself and is his conceptual system about his surrounding things and phenomena. The construction of this system before mastering the language is a non-verbal stage of the persons' education. At this stage, the person gets acquainted with the objects available the direct perception (Pocheptsov, 1990:112). 
According to E. Sweetser, the conceptual form of the world picture is its "image", not clothed in any system of signs. The world division with the help of language is carried out by superimposing the conceptual frame on the world (i.e., by highlighting concepts) and situational frame (i.e., by highlighting situations) (Kravchenko, 1997:8). From all this it follows that, on the basis of the world knowledge, a person, as a result of accumulated experience, creates the conceptual world picture, peculiar only to him, and tries to verbalize it through the prism of the sign system (Kozlov, Pruzhanin, 1984:99).

The consequence of this process is the emergence of the so-called linguistic world picture, where the language is connected with reality through a sign correlation, that is, it displayed in a sign way (Popova, 2004).

The cultural component of a word in a particular language can be identified in dictionary definitions or directly in texts that compare different synchronous sections of the history of a given society, that traditional stereotypes of thinking in relation to certain events, different social groups representatives' linguistic behavior of, etc.

Vocabulary for food and drink designation is the linguistic humanity picture immediate component. The study of ethno-culturally labeled vocabulary is a priority for modern linguists both in Ukraine and abroad. For example, the Ukrainian researcher N. Guyvanyuk, believes that vocabulary in speech systems is a layer of tokens with a "cultural component", which reflects particular people cultural realities and makes its identity different from other ethnic groups.

The subject of linguistic research were the names of authentic foods and dishes, which is reflected in a number of scientific articles, in particular in the works of V. Nimchuk, V. Horobets, V. Karpova, N. Ostash, I. Oshchipko, O. Perlyuk, A. Popovsky, V. Suprunenko. I. Chepiga and others.

Such names form a separate vocabulary layer a part of which is international or denotes realities of different cultural traditions, other nominations are used to express authentic beverages and dishes.

\section{Vocabulary for Food and Drink Designation in the Vernacular}

Here are some examples chosen from dialect, regional, etymological dictionaries and ethnographic materials of Ukrainian, English, French and Polish languages of the second half of the 19th century and the beginning of the 20th century. We propose to consider ways of ethno-cultural motivation of the vernacular nominations.

The names of beverages and dishes are verbalized by certain semantic models.

\section{Names motivated according to the product they are made of:}

The nomination тернівка «a drink that is made of blackberries» - the name of an alcoholic beverage comes from the name of its ingredients. For example: Була і вишнівка, i тернівка, і булівка» (Кв.-Осн.) can be compared to: «Він вибрав кілька пригорщів самих достиглих веприн, великих, як терносливи» (Фр.).

We can also see the same type of motivation in the nomination циитринівка "Vodka, infused with peel of lemon» - the name comes from the preparation product.

Nomination арак, гарак designates a strong alcoholic beverage from rice or palm juice "rum" r. арак, p. ch. sl. v. arak, shr. арак, sl. Arak is a borrowing from Western European languages; fr. arack, g. arak, derive from ar. 'araq "palm juice". This drink belongs to the group of spirits. 
Nomination mazzard [mae'zad.] is used to nominate brandy, drink from small black cherries.

The word plum also spelled plumb "a drink made of plums can also be a type of wine" the name comes from the ingredient.

The word cherry is a kind of spruce - an alcoholic drink made from cherries. For example: "The day on which the neighborhood formerly assembled at Martindale to pick wild cherries, and make merry at the village inn, ib." - the name of the drink comes from the name of its main ingredient.

Nomination egged ale I English dialects designates ale made by adding and mixing eggs.

Nomination куліш is borrowed from the Hungarian word köles - "millet".. Hence is its other name - the field porridge. Звідси й інша його назва - польова кама. Cossacks cooked it daily during the military campaigns: Чуб. VII. 439. Хочкуліш, та з перием. Ном. № 5072. Тут з салом галушки лигали, лемішку і куліш глитали.

The lexeme юшка soup is a derivative of the юха. A liquid dish that is the result of a meat or vegetable broth. In the Old Ukrainian language, the roxa (from pol. * Juxa) meant any meat, fish, vegetable soup. The word functioned in the ancient Ukrainian language with initial $y$ and primary semantics. The historians of the language consider Ukrainian and Belarusian lexemes roxa to be borrowing from the Polish language.

Borsch in Old Ukrainian was a drink made from the red beet. In the vernacular of the XVIIIth century it already has the meaning of the soup with beets, and the plant itself in the literary language became known as "borscht". The plant has a similar name in other Slavic languages: Ukrainian: борщівнік, Czech bolševnik, in some Slavic languages, as well as in Lithuanian, the original verb was preserved: Slovenian brك̌š, Polish barszcz, bařsć, Belarusian борич.

In Polish barszcz is the acidified or aged vinegar from the usually beetroot).

Polish word kaszanka has the meaning of a bowel filled with buckwheat and blood.

\section{Names motivated according to the method of preparation}

Drink mepmyxa means "A drink of strawberries, ground with sugar and mixed with vodka". Ukrainian терти means to grind.

The name bree also spelled brew, brie [bri.] has a meaning "Liqueur, a juice in which everything has been soaked or boiled; broth, soup, sauce».

Nomination of деру́н, designates potato pancakes. It is believed that this dish came to Ukrainian cuisine from Belarusian cuisine where, in turn, this dish came from Germany at the end of the 19th century. According to another version, the distribution of potato pancakes and a number of other potato dishes (roasted potatos, dumplings) in the territory of Ukraine, mostly in Polissia, started even earlier - in the second half of the eighteenth century.

Nomination of hotch-potch, (something mixed). Realizes the following meanings: 1 . Broth cooked with meat and vegetables together; 2. stew, a dish consisting of various ingredients, cooked together: Irish stew. Sc. A dish of broth made with mutton or lamb cut into small pieces, along with green peas, carrots, turnips, sometimes parsley or celery, served with meat in it.

\section{Names motivated according to the taste qualities}

The name of the drink медок "Variety of table grape French wine" showes the sweet taste of the wine. Ukrainian мед means honny.

The word slock rverbalizes an alcoholic beverage after which it gets dry in the throat. The first meaning of the nomination is to extinguish the fire. 


\section{Names motivated according to the method of serving and consumption}

The name наливка "Sweet liquor, infused with berries or fruits" characterizes the taste of the drink and indicates that it is sweet. For example: «Не я $\dddot{\imath}$ з ума звожу, зводе іï темна нічка, солодкий мед, наливочка». (Грінч.).

Nomination запіканка (casserole) 1."a spirit drink with spices that is aged for some time in a hot oven» 2. "a dish prepared by baking methods" - the name comes from the method of cooking.

Drink льодок "a drink with honey and alcohol, which is drunk chilled".

The name klunk is a kind of a liqueur that is swallowed with one sip.

Nomination booze is used to indicate strong drinks.

The name dram has two meanings 1. a kind of whiskey" [dram.] 2. a glass of whiskey with pepper. For example: "If the child was taken to a neighbor's house at a distance. The person first to receive bread and cheese and a dram, Gregor Flk-Lore »(1881)

\section{Names motivated according to the outlook}

The word бурда "a murky drink; belch; tasteless liquid or food» is borrowed from the Tatar language, apparently through Russian mediation. The original word ment "a turbid drink, a mixture of different liquids". It is a suffixal formation from the base of the turk. bor- / bur- "twist". Nomination воронець "a drink from vodka with honey" characterizes something as obscure. For example: «Він як той воронець».

Lexeme галушка, (dumplings) галушка, кусочекъ тғста, сваренный въ водг или молокг, клецка, різані галушки, рвані галушки, - смотря по способу приготовленія. Іди, доню, вечеряти, бо галушечки скипіли. has the origin of the word «галка» («a ball», «a patch”). Polish gatka («a ball»),Czech halka («the plant sickness»), словен. galka («an ink nut»).

\section{Names motivated according to the size and richness of the components}

Nomination poor "type of beer" also written peer, pore, pour, puir, pure - means beer, small beer; a weak drink; beverage that belongs to the group of weak alcoholic beverages.

Polish word mizeria designates a salad cut into slices of raw cucumbers. The word is motivated with simplicity of its components.

\section{Ritual dishes names}

The bridal names a drink that is tasted by guests, a drink that is poured by the bride and groom.

Nomen bridge, sb. Sc. [br-di.] A small mutton or beef pie with gravy in it, about the size of a teacup saucer. Frf. Pie, a small lambmeal pie with sauce in it, the size of a saucer.

The French cake bûche de Noël is a traditional dessert served near Christmas, especially in Belgium, France, Switzerland, Canada, Lebanon and several former French colonies, as well as the United Kingdom and Catalonia. Made of sponge cake to resemble a miniature actual Yule log, it is a form of sweet roulade.

The original Yule log recipe emerged during the 19th century. It is traditionally made from a genoise, generally baked in a large, shallow Swiss roll pan, iced, rolled to form a cylinder, and iced again on the outside. The most common combination is basic yellow sponge cake and chocolate buttercream, though many variations that include chocolate cake, ganache, and icings flavored with espresso or liqueurs exist.

Yule logs are often served with one end cut off and set atop the cake, or protruding from its side to resemble a chopped off branch. A bark-like texture is often produced by dragging a fork through the icing, and powdered sugar sprinkled to resemble snow. Other 
cake decorations may include actual tree branches, fresh berries, and mushrooms made of meringue or marzipan.

The name buche de Noël originally referred to the Yule log itself, and was transferred to the dessert only after the custom had fallen out of use, presumably during the first half of the 20 th century. By 1945 , it referred to the cake.

Names are related to the names of people, mythological and biblical characters

The name apostles' drink appears in English dialects: 'Pit drink a weak beer brewed for the allowance dnnk in mines .... was called' Apostles' drink, 'because eleven apostles carnecwater and one carried malt, Chronicle, Oct. 25, 1901). ".

The nomination adam's ale belongs to a group of biblical motifs. For example: "A Rechabite poor Will have to live, And drink or Adam'sale, PRIOR Wandering Pilgrim".

\section{Conclusions and suggestions}

The study of the vernacular vocabulary remains one of the crucial issues of modern linguistics. Vernacular language is a permanent phenomenon in which the collective memory preserves information about primordial folk culture, responds to socio-economic and culturalhistorical shifts in society.

Vernacular language captures the genetic natural link between developmental stages of the nation's culture and language. In this regard, dynamic research processes in the vocabulary thematic group that represents the most conservative part of the material culture of different cultures, in its regional expression, acquires the particular relevance.

A systematic analysis of the dynamics of the thematic group of food and beverage names gives the possibility to draw a number of generalizations and conclusions.

The natural and geographical factor of the European continuum determines plant and animal basis of nutrition, which at the beginning of the 19th century occurs at a qualitatively higher level. The cooking information is verbalizing Folk cultural nomenclature constituting an open term system for which is characterised wirh a dynamic processes caused by extralinguistic and intralingual factors. Culinary folk terms have a dualistic nature: reproducing material culture, are the manifestations of spiritual culture.

\section{References}

Brutyan, G. A. (1973). Language and picture of the world. Scientific reports of higher education. Moscow: Philosophical sciences, 84-112. [in Russian].

Humboldt, von W. (1985). Language and philosophy of culture. Moscow: Prohress. [in Russian].

Karasik, V. I. (2005). Anthology of concepts. Karasik, I. V., Sternin, I. A. (Eds.). Volgograd: Paradyhma. [in Russian].

Karaulov, Yu. N. (1996). General and Russian ideography. Moscow: Science. [in Russian].

Kozlov, A. I., Pruzhanin, B. I. (1984). Language and cognition (the experience of a methodological examination of the prospects of linguistic theory). Moscow: Nauka. [in Russian].

Kravchenko, A.V. (1997). The phenomenology of meaning and the importance of phenomenology in language. Moscow: Moscow State University. [in Russian]. 
Kubryakova, E. S., Shakhnarovich, A. M., Sakharny, L.V. (1991). The human factor in language. Language and the generation of speech. Kubryakova, E. S. (Ed.). Moscow: Science. [in Russian].

Pocheptsov, O. G. (1990). Linguistic mentality: a way of representing the world. Questions of linguistics, No. 6, 86-97. [in Russian].

Popova T.G. (2004). National-cultural semantics of the language and cognitivesociocommunicative aspects: on the material of English, German and Russian languages: dis. doc. filol. sciences. Moscow: MGOU. [in Russian].

Serebrennikov, B. A., Kubryakova, E. S., Postovalov, V. I. (1988). RHFL - The role of the human factor in language. Moscow: Science. [in Russian]. 